\title{
A Iniciativa Probatória do Juiz no Âmbito da Instrumentalidade do Processo Civil
}

Aretha Ferreira Fernandes

\begin{abstract}
RESUMO
O presente trabalho pretende analisar o instituto da prova no processo civil, aprofundando o estudo sobre a participação do juiz na sua determinação e produção. Analisam-se as várias opiniões doutrinárias acerca do tema como também os princípios processuais e constitucionais referentes à participação dos sujeitos processuais na produção da prova, tais como o princípio dispositivo, o contraditório, a igualdade processual, a imparcialidade e as regras sobre o ônus da prova. Diante da reformulação destes princípios, a partir de uma visão publicista do processo, conclui-se pela possibilidade da participação efetiva não apenas das partes, mas também do juiz.
\end{abstract}

Palavras-chave: processo- instrumentalidade- princípios- juiz- provas.

\begin{abstract}
The probative initiative of the judge within the ambit of the civil process' instrumentality

The present work aims to analyze the institute of the proof in the civil process and deepen the study about the judge's participation in its determination and production.

It analyzes numerous doctrinal opinions about this topic and also the procedural and constitutional principles referring to the participation of procedural subjects in the production of proof such as the dispositive principle, the contradictory, the procedural equality, the impartiality and the rules about the burden of proof. With the reformulation of these principles, as from a publicist view of the process, the work concludes for the possibility of an effective participation not only of the parties, but also the judge.
\end{abstract}

Keywords: process, instrumentality, principles, judge, proof

\section{INTRODUÇÃO}

O tema do aumento dos poderes do Juiz para conduzir o processo especialmente, em se tratando deste trabalho, o processo civil, é uma tendência que vem crescendo no Brasil e no direito alienígena, adquirindo-se uma nova conotação a partir do liame entre a atividade probatória do magistrado e a instrumentalidade do processo.

A instrumentalidade do processo, base para o estudo do tema, é um assunto relativamente novo, que está ganhando espaço na doutrina e na jurisprudência no momento atual.

O fenômeno da instrumentalidade está intimamente ligado com o que parte da doutrina intitula de constitucionalização do processo civil, na medida em que o processo é legítimo instrumento para aplicação e proteção dos direitos e garantias fundamentais assegurados na 
Constituição. Tal ligação é bastante perceptível a partir da reserva axiológica e normativa que a Constituição confere ao processo. Este deve impregnar-se dos valores essenciais que permeiam o texto constitucional, os quais, embora abstratos e necessitando da devida concretização, apontam a construção de uma sociedade livre, justa e solidária.

Sob essa nova perspectiva, diz-se que o processo atual, opondo-se à idéia de autonomia da vontade, está voltado para uma ordem de valores e princípios acima dos direitos controvertidos das partes (ordem pública). Hoje, o Estado foi colocado como centro das atenções no direito processual, que deste modo, assumiu uma conotação eminentemente publicista.

Assim, várias mudanças estão ocorrendo e uma das mais visíveis é o fortalecimento dos poderes do juiz, sobretudo no campo probatório.

Neste contexto, necessário se faz uma releitura do princípio dispositivo, segundo o qual, cabe às partes a iniciativa de instruírem o processo com a prova daquilo que foi alegado, proporcionando ao juiz os melhores instrumentos de apuração da verdade. O princípio está consagrado em vários artigos do Código de Processo Civil (CPC), entre eles os artigos $2^{\circ}$, 262,333 e 460 .

Desse modo, pretende-se analisar e desenvolver esta nova leitura do princípio dispositivo, restringindo seu alcance à iniciativa das partes quanto às alegações, não assim quanto à prova dos fatos alegados, que deixou de ser privativa das partes, passando ser também de iniciativa do juiz.

Não se quer concluir, porém, pela adoção do princípio inquisitivo e tampouco pela adoção de uma postura arbitrária ou parcial do juiz, devendo-se frisar que seus poderes instrutórios são limitados.

Pretende-se, assim, analisar, sob a ótica da instrumentalidade do processo civil, os poderes de iniciativa do Juiz para produzir as provas e relacioná-los com os princípios processuais, incluindo os de natureza constitucional.

No mesmo norte, buscamos também analisar as várias opiniões e divergências doutrinárias acerca do tema. Para isso, foram analisados o direito subjetivo à prova e os aspectos fundamentais da atividade instrutória do Juiz.

Assim, tem-se como objetivo do presente trabalho desenvolver uma ampla concepção do processo, através da rediscussão de dogmas, regras e conceitos à luz da instrumentalidade, culminado no aprimoramento da prestação jurisdicional, entendida sob uma ótica participativa. 


\section{Instrumentalidade do Processo}

A idéia de instrumentalidade do processo surge a partir da crítica ao estudo excessivamente introspectivo do direito processual e de seus conceitos fundamentais. Cândido Rangel Dinamarco foi o precursor da idéia de instrumentalidade, inserindo-a num terceiro momento metodológico do direito processual, superada as fases sincretista e autonomista anteriores.

$\mathrm{Na}$ fase sincretista, que vigorou até meados do século XIX, não se tinha consciência da autonomia da relação jurídica processual em face da relação jurídica de direito material que ligava os sujeitos do processo. Assim, a ação se confundia com o próprio direito subjetivo material que, uma vez lesado, adquiria autorização pela lei de ser reparado em juízo.

Em seguida, surge a fase autonomista do direito processual, por influência das idéias racionalistas do "século das luzes". A postura dos processualistas desta fase revelou-se obcecadamente autonomista no contorno das investigações do direito de ação, permitindo-se assinalar o seu caráter eminentemente abstrato, desvinculado do direito material sob apreciação judicial.

Assim, surge um movimento, desencadeado pelos processualistas modernos, que passa a não se satisfazer mais com conceitos processuais destituídos de finalidades teleológicas, baseados apenas em abstrações dogmáticas, sem, no entanto, terem uma visão nítida dos objetivos e resultados a serem obtidos pelo processo.

Com efeito, o processo, assim como todo instrumento, é um meio que só se legitima se for aplicado em função dos fins a que se destina. Assim, o raciocínio teleológico deve abranger os escopos do processo, ou seja, os propósitos que devem nortear a sua instituição e a conduta dos agentes estatais que o utilizam. ${ }^{1}$

Haja vista que o Estado é o responsável pelo bem-estar da sociedade e dos indivíduos, estando o bem-estar ameaçado por conflitos entre pessoas, é dever do Estado se valer do aparelhamento processual, para, através da jurisdição, eliminar o conflito de interesses e devolver à sociedade a paz aspirada.

Assim, pode-se dizer que o processo é, portanto, um instrumento de pacificação social, na medida em que através dele são concretizadas as promessas inscritas nas normas de direito material. Percebe-se, destarte, a importância e o alcance da instrumentalidade, ao alertar para a necessária efetividade do processo e também para que ele não seja um fím em si mesmo, sendo capaz de servir à ordem jurídica justa.

\footnotetext{
${ }^{1}$ DINAMARCO, Cândido Rangel. A instrumentalidade do processo. 11 ed. São Paulo: Malheiros, 2003. p. 181.
} 
Como decorrência direta do caráter instrumental assumido pelo processo, este passou a ser visto como um instrumento eficaz de proteção das pessoas, tornando-se um canal social de participação democrática, pautado no modelo de proteção do ser humano trazido a lume com a Constituição de 1988, dando origem ao fenômeno conhecido como constitucionalização do processo.

A instrumentalidade, portanto, seria o núcleo dos movimentos pelo aprimoramento do sistema processual, sendo a constitucionalização do processo a sua decorrência direta, imprimindo a este natureza protetora e aplicativa dos direitos e garantias fundamentais consagrados na Carta Magna.

Na lição de Marcus Firmino Santiago, "ao mesmo tempo em que o Processo serve para materializar as promessas constitucionais, por elas deve ser impregnado, amoldando-se, tanto na sua forma quanto em seu conteúdo, aos parâmetros estipulados na Carta Magna para o eficaz exercício da função jurisdicional." ${ }^{2}$

Assim, no cenário jurídico atual, buscam-se adequar as regras processuais aos valores constitucionais fundamentais. Não basta, porém, uma mera adequação formal dos procedimentos judiciais à ordem constitucional, é preciso que os operadores do direito reconheçam no processo um mecanismo eficaz de exercício da jurisdição, com reflexos diretos no seu conteúdo, na forma como é decidido e conduzido pelo órgão judicial. ${ }^{3}$

Diante deste contexto, há que se contar com um papel atuante e ativo do juiz, (haja vista ser ele o diretor do processo), consciente de sua função de promover a paz social. A instrumentalidade é, pois, tomada como premissa para a defesa do aumento na participação do juiz na instrução da causa, assim como na liberdade ao apreciar o resultado da instrução.

\section{A Prova no Processo Civil}

2.1 A atividade do juiz de reconstrução dos fatos

A fim de se obter uma melhor compreensão da atividade do juiz, diz-se que este se assemelha ao historiador, que tem a missão de reconstruir os fatos no tempo e no espaço. $\mathrm{Na}$

\footnotetext{
${ }^{2}$ SANTIAGO, Marcus Firmino. Constitucionalização do processo civil. Tex.com.br.Seção Artigos. Disponível em <http://www.tex.pro.br/wwwroot/01de2005/constitucionalizacao_do_processo_claudio_firmino.htm> Acesso em: 05 jun. 2010.

${ }^{3}$ SANTIAGO, Marcus Firmino. Constitucionalização do processo civil. Tex.com.br.Seção Artigos. Disponível em <http://www.tex.pro.br/wwwroot/01de2005/constitucionalizacao_do_processo_claudio_firmino.htm>

Acesso em: 05 jun. 2010.
} 
relação jurídica processual, o autor deve levar ao juiz a afirmação dos fatos que correspondem à sua pretensão; ao passo que o réu, em sentido oposto, deve contrapor as afirmações de fato feitas pelo autor. Assim, em relação à afirmação de ambas as partes, pode haver dúvida quanto à veracidade dos fatos alegados.

Isso ocorre porque fatos não são dados, algo pronto e acabado, mas sim algo a ser construído, investigado, e a conclusão a que se pretende chegar é que esta investigação resulta da atividade probatória das partes juntamente com o juiz.

As dúvidas em relação à veracidade das afirmações alegadas pelas partes constituem as questões de fato que devem ser resolvidas pelo juiz, diante da prova dos fatos pretéritos.

Assim, a prova é um instrumento por meio do qual são fornecidos ao juiz os elementos necessários para a reconstrução dos acontecimentos passados, com a finalidade de que ele possa formar o seu convencimento acerca da veracidade ou falsidade dos fatos históricos alegados pelas partes. ${ }^{4}$

Observa-se que o conceito de prova está intimamente ligado à sua finalidade. É ela o instrumento que convencerá (ou não), o magistrado em relação aos fatos controvertidos do processo alegados pelas partes. Sem analisá-la e valorá-la, não há como o magistrado fazer juízo de valor e proferir a sua decisão.

\subsection{Noção tripartida da prova, objeto e meios de prova}

$\mathrm{Na}$ verdade, em razão de várias definições e conceitos adotados pela doutrina, diz-se que a prova possui concepção plural, destacando-se, como se refere Eduardo Cambi, a "noção tripartida da prova", que a conceitua como atividade, meio e resultado. ${ }^{5}$

Como atividade, a prova quer dizer instrução ou conjunto de atos processuais realizados pelo juiz e pelas partes, com o objetivo de reconstruir os fatos no processo, sendo que tal atividade se constitui como suporte tanto às partes, em relação à afirmação de suas pretensões em juízo, quanto ao juiz, no momento de formar sua convicção na sentença.

Como meio, a prova é sinônimo de instrumento pelo qual as informações sobre os fatos são levadas e introduzidas ao processo. Assim, nesse sentido, a prova visa à formação do

\footnotetext{
${ }^{4}$ Cumpre ressaltar que os fatos pertencem ao passado, mas as questões levadas ao processo podem estar acontecendo no presente ou terem consequências no futuro.

A título de exemplo, pode-se citar o seqüestro de bens do casal, nas ações de separação, se ficar provado que um dos cônjuges os está dilapidando (art. 822, III, CPC). Percebe-se que não é necessário que todo o patrimônio do casal já esteja dilapidado, para configurar lesão ou ameaça a direito. Basta provar que o cônjuge colocou anúncio nos classificados do jornal, por exemplo, com intenção de alienar o bem.

${ }^{5}$ CAMBI, Eduardo. Direito Constitucional à prova no processo civil. São Paulo: Revista dos Tribunais, 2001. v. 3. p. 48.
} 
convencimento do juiz (iudict fit probatio) sobre a existência ou não dos fatos constantes do thema probandum.

Como resultado, a prova significa êxito ou valoração realizada pelo juiz no momento da decisão. Nesse aspecto, a noção de prova engloba aspectos objetivos (atividade, meio) e também subjetivos (está voltada para a busca da verdade a ser alcançada no processo).

Quanto ao objeto da prova, este somente pode ser alegações de fato pertinente, controvertido ou relevante.

Assim, fatos que não dizem respeito à causa (impertinentes), aqueles que não são objeto de divergência entre as partes (incontroversos), ou não têm importância para a decisão da causa (irrelevantes), ficam excluídos da atividade probatória. O mesmo pode-se dizer quanto aos fatos notórios (conhecidos de todos), os afirmados por uma parte e confessados pela outra (desde que não se trate de direito indisponível, conforme CPC, art.351), os que gozam de presunção legal de existência ou veracidade (CPC, art. 334) e também os fatos impossíveis (apesar de se admitir a prova dos fatos improváveis).

A regra geral em relação aos meios de prova está contida no CPC, art. 332, in verbis: “Todos os meios legais, bem como os moralmente legítimos, ainda que não especificados neste Código, são hábeis para provar a verdade dos fatos, em que se funda a ação ou defesa."

Consideram-se meios de prova, portanto, todos aqueles estabelecidos por lei, seja de direito público, seja de direito privado. Apesar da generalidade da norma contida no artigo supracitado, o CPC regula expressamente os seguintes meios de prova: depoimento pessoal (arts. 342 a 347); confissão (arts. 348 a 354); prova documental (arts. 364 a 399); testemunhal (art. 400 a 419); prova pericial (arts. 420 a 439) e a inspeção judicial (arts. 440 a 443).

Esses são os meios de prova com que o juiz entra em contato diretamente, seja na sua admissão, através de requerimento das partes; seja na sua participação, ao determiná-las de ofício; seja na sua valoração, no momento da sentença.

\subsection{Limites à reconstrução dos fatos}

Embora a prova tenha a finalidade de propiciar a reconstrução dos fatos no processo, nem sempre ela atinge o seu papel, pois há uma série de limitações que dificultam ou impedem que a reconstrução desses fatos corresponda à realidade.

O juiz, ao formar sua convicção, deve considerar somente os elementos de prova contidos nos autos, não lhe sendo lícito utilizar-se de seus conhecimentos pessoais. Isso ocorre porque o objeto da investigação sempre é delimitado pelas partes; assim, o acesso do 
juiz aos fatos ocorre somente através dos meios de prova, mesmo que já tenha conhecimento pessoal sobre os fatos ocorridos.

Dessa forma, o juiz deve se limitar a reconstruir os fatos de acordo com o interesse do autor e do réu, evitando-se, assim, atribuir critérios eminentemente subjetivos aos fatos, quebrando sua imparcialidade e não sujeitando as partes ao contraditório, o que poderia leválo a proferir decisão arbitrária, difícil de ser controlada pelas partes.

A proibição da utilização dos conhecimentos privados pelo juiz, todavia, comporta exceções, previstas na lei, tal como o uso de máximas da experiência e dos fatos notórios. Estes são os fatos comumente conhecidos pela cultura de determinada sociedade à época da decisão judicial. Já aquelas, nos dizeres de Moacyr Amaral Santos, ${ }^{6}$ são "porção de noção extrajudicial" que possui o juiz, fruto de sua cultura, formada por seus conhecimentos sociais, científicos, artísticos, políticos ou práticos. São juízos de valor formados sobre o que comumente acontece e percebidos por qualquer pessoa de cultura média. ${ }^{7}$

Por outro lado, o juiz também encontra limites à sua liberdade de valoração da prova, sendo que algumas já são pré-valoradas pela lei (provas legais), devendo o juiz apenas verificar se a prova foi formalmente prestada. Há ainda situações em que o ordenamento jurídico não admite a utilização de certos meios de prova, por considerá-las ilegais ou ilegítimas. Além disso, o juiz tem obrigação de dizer o direito no caso concreto, sendo-lhe vedado o pronunciamento do non liquet, como reza o art. 126 do CPC: "O juiz não se exime de sentenciar ou despachar alegando lacuna ou obscuridade da lei...".

O juiz tem o dever de decidir, ainda que esteja em dúvida, por isso o legislador lhe confere instrumentos hábeis a estabelecer critérios de racionalização da dúvida, permitindo o julgamento e evitando decisões arbitrárias. Nesses casos, quando as partes têm a oportunidade de utilizar a prova, mas não se valem do mecanismo probatório, o juiz utilizará o sistema do ônus objetivo da prova. Isso quer dizer que a parte que tem o ônus de provar e não o faz, assume os riscos da existência ou eficácia dos fatos controvertidos, pois os fatos que não forem provados serão considerados inexistentes pelo juiz.

Portanto, a conjugação desses fatores limita a investigação dos fatos pelo juiz e consequentemente, dificulta a busca da verdade real.

\footnotetext{
${ }^{6}$ SANTOS, Moacyr Amaral. Primeiras linhas de direito processual civil. 19 ed. São Paulo: Saraiva, 1998. p. 337.

${ }^{7}$ É importante notar que, mesmo nesses casos, recomenda-se que o juiz, para evitar decisões arbitrárias, dê oportunidade ao contraditório prévio.
} 


\section{A Prova e a Busca da Verdade}

Para que uma decisão judicial seja justa, é necessário que o acertamento dos fatos no processo seja feito de forma correta e suficiente. Para tanto, deve-se buscar a verdade como meio a fim de se atingir tal decisão.

A idéia de prova, naturalmente, e não apenas no processo, evoca a idéia de busca da verdade. Partindo do pressuposto de que os atos praticados no processo têm como objetivo colocar o juiz em condições de se pronunciar sobre a demanda, aí tendo enorme importância a “execução das provas", tem-se que um dos princípios essenciais (senão a função essencial) do processo de conhecimento é a busca da verdade substancial.

Para Mittermayer, a "verdade é a concordância entre um fato ocorrido na realidade sensível e a idéia que fazemos dele." 8 Tendo o magistrado a tarefa de reconstruir os fatos, a fim de que a aplicação da norma ao caso sub judice seja feita de forma correta, é certo que a medida dessa adequação está na maior ou menor aproximação da hipótese descrita na regra com a descoberta da verdade.

É a partir desta descoberta que o julgador conseguirá saber como se passaram as coisas, a história, o seu valor, enfim, chegará mais perto da verdade. Assim, a busca da verdade está intimamente ligada com a qualidade da prestação jurisdicional que se deseja obter do Estado.

E mais: a busca da verdade legitima a função judicial, além de servir também como válvula reguladora, pois a atuação do magistrado somente será legítima dentro dos parâmetros fixados pela verdade por ele reconstruída no processo.

Contudo, voltando o olhar ao estágio atual das demais ciências, constata-se que, tanto no processo como em outros ramos científicos, a verdade absoluta nunca é atingida, sendo que jamais se poderá afirmar que o produto encontrado efetivamente corresponda à realidade.

Diante dessa afirmação, observa-se que há uma crise na busca da verdade no processo, o que muitas vezes acarreta a perda de credibilidade na própria justiça. ${ }^{9}$ Com efeito, a reconstrução de um fato do passado sempre dá margem a certo grau de subjetividade, pois a realidade invariavelmente depende do ponto de vista particular de cada pessoa, que a absorve

\footnotetext{
${ }^{8}$ MITTERMAYER, C. J.A, apud MARINONI, Luiz Guilherme; ARENHART, Sérgio Cruz. Manual do processo de conhecimento: a tutela jurisdicional através do processo de conhecimento. São Paulo: Revista dos Tribunais, 2001. p. 276.

${ }^{9}$ Giuseppe Capograssi propõe como solução desse problema que se recupere "a suprema ingenuidade de crer na verdade, porque a sorte do direito depende dessa crença, e também porque a verdade dá sentido ao processo, já que deve ser considerada a 'mãe da justiça'." CAPOGRASSI, Giuseppe, apud CAMBI, Eduardo. Direito Constitucional à prova no processo civil. São Paulo: Revista dos Tribunais, 2001. v.3. p. 77.
} 
à sua maneira. Assim, não é raro que as partes "distorçam" a realidade dos fatos, de modo que as suas alegações influenciem favoravelmente a decisão judicial.

Não se pode ignorar que também o juiz, que faz a reconstrução dos fatos, possui certo subjetivismo ao receber e valorar a evidência concreta. Some-se a isso o fato de que a eficácia do meio probatório está condicionada muitas vezes a formalidades. Além disso, alguns meios de prova não são admitidos no processo, com o intuito de resguardar outros interesses (o direito à intimidade, por exemplo). Tudo isso, de certa forma, limita a atividade probatória e exclui a possibilidade de que o juiz efetivamente encontre a verdade.

Diante desse quadro, constata-se que o compromisso que o processo tem com a verdade não é tão implacável como aparenta ser. ${ }^{10}$ Neste contexto, Cambi utiliza-se de três critérios de justiça que podem ser apontados para a decisão, a saber: a) a correção da escolha e da interpretação da regra jurídica aplicável ao caso concreto; b) a reconstrução fiel dos fatos relevantes do caso; c) a utilização de um procedimento válido e justo para chegar a decisão. ${ }^{11}$

É necessário registrar que todos estes critérios devem ser conjugados, para que o escopo processual seja alcançado.

Diante de todo o exposto, conclui-se que os instrumentos humanos são precários na busca da verdade, se revelando insuficientes para que se possa atingi-la com perfeição. Contudo, nos parece ser melhor buscar a verdade possível do que simplesmente não buscá-la. Assim, quanto mais seguros e abundantes forem os elementos que se puderem obter das provas, tanto menor será a margem de erro do juiz ao sentenciar.

\section{Aspectos Fundamentais da Atividade Instrutória do Juiz}

\subsection{Princípios processuais}

O juiz, ao dirigir o processo, deve se orientar pelos princípios processuais, cuja função é indicar os meios, as diretrizes e o modo de agir em juízo aos sujeitos processuais, a fim de contemplar os valores que o sistema processual tem por finalidade alcançar. Vários princípios processuais emanam diretamente da Constituição, são os chamados princípios de natureza

\footnotetext{
${ }^{10}$ Marinoni e Arenhart percebem uma verdadeira contradição neste aspecto, pois a sociedade espera de um juiz "que seja justo e apto a desvendar a essência verdadeira do fato ocorrido no passado, mas reconhece-se que a falibilidade humana e o condicionamento dessa descoberta às formas legais não lhe permitem atingir esse ideal." MARINONI, Luiz Guilherme; ARENHART, Sérgio Cruz. Manual do processo de conhecimento: a tutela jurisdicional através do processo de conhecimento. São Paulo: Revista dos Tribunais, 2001. p. 282.

${ }^{11}$ CAMBI, Eduardo. Direito Constitucional à prova no processo civil. São Paulo: Revista dos Tribunais, 2001. v.3. p. 77.
} 
constitucional, verdadeiros postulados assumidos pelo próprio Estado, como objetivos a serem por ele alcançados. ${ }^{12}$

Faz-se mister destacarmos, neste momento, a relação entre os poderes instrutórios do juiz e os princípios processuais e constitucionais referentes à participação dos sujeitos processuais na produção da prova,

Pretende-se demonstrar, a partir da reformulação de tais princípios, a legitimidade dos poderes instrutórios do juiz.

\subsection{Princípio dispositivo}

Segundo este princípio, na "divisão de tarefas" no processo, deve haver a supremacia da iniciativa das partes sobre o poder estatal, devendo o juiz deixar ao encargo destas o debate processual, adotando postura menos ativa.

Assim, tal princípio se revela como oposto ao princípio inquisitivo, segundo o qual tanto o impulso oficial como a condução do processo é atribuída ao juiz, sem aguardar a iniciativa das partes.

Pode-se dizer que o princípio dispositivo surgiu em decorrência do Estado liberal, onde o processo era considerado como um contrato ou quase-contrato, sendo que cabia exclusivamente às partes o seu impulso e resultado, prevalecendo a autonomia da vontade. Assim, a formação do princípio dispositivo parte do pressuposto de que a matéria levada ao Estado-juiz para solução dos conflitos será sempre e em qualquer caso de direito disponível.

$\mathrm{Na}$ realidade, conforme entendemos, seu fundamento não é a natureza disponível do direito material, pois, se assim fosse, tal princípio não se aplicaria aos processos que versam sobre direitos indisponíveis.

Tomemos como exemplo uma das manifestações comumente incluídas no princípio dispositivo, qual seja, a proibição do exercício da jurisdição sem que haja a iniciativa da parte. Tal proibição se aplica tanto aos processos que versem sobre direitos disponíveis como aqueles que versem sobre direitos indisponíveis. Assim, o juiz não pode iniciar, de ofício, um processo que trata sobre direitos da personalidade (direito à vida, à integridade pessoal, etc.), ainda que seja indisponível.

Por outro lado, o juiz pode, de ofício, se as partes assim não o fizerem no prazo legal, instaurar o processo de inventário (art.989 CPC), mesmo em se tratando de direito disponível.

\footnotetext{
12 Vide Constituição Federal, arts. $1^{\circ}$ a $4^{\circ}$, onde estão positivados os princípios fundamentais do Estado brasileiro.
} 
O mesmo pode-se dizer em relação à atividade probatória. Conclui-se pela leitura dos artigos 130, 131, 262, 342, 355, 281, 418 e 440 do CPC que os poderes instrutórios do juiz não são maiores ou menores se o direito material for disponível ou indisponível. Não há qualquer distinção a respeito.

A disponibilidade da relação jurídica de direito material não infere, necessariamente, na disponibilidade da relação jurídica processual, devido esta, de natureza pública, ter natureza diferente daquela, que é privada. ${ }^{13}$

Assim, o princípio dispositivo deve expressar a limitação imposta ao juiz em virtude da disponibilidade do direito das partes, tais como a liberdade para desistir da ação, formular transação, renunciar ao direito pleiteado ou reconhecer a juridicidade do pedido da parte contrária. As restrições em relação à iniciativa do processo (princípio da ação ou da demanda) e à instrução da causa, não têm qualquer nexo com a relação material levada ao processo, não decorrem, portanto, do chamado princípio dispositivo.

Pretende-se demonstrar, portanto, que o princípio está ligado fundamentalmente ao objeto litigioso da relação jurídico-substancial, ou seja, aos atos processuais que as partes praticam no curso do processo; embora a maioria da doutrina reserve a aplicação do princípio à iniciativa probatória das partes, restringindo, por conseguinte, a produção de provas pelo julgador.

Não obstante a polêmica em relação ao alcance do princípio é imprescindível reconhecer que há uma mitigação do princípio dispositivo no processo civil moderno, a ponto de permitir uma ampla gama de atividades instrutórias de ofício, conforme já constatamos em referência aos dispositivos que permitem a iniciativa probatória e o impulso oficial, acima mencionados.

Vigora hoje, portanto, o sistema de conciliação do princípio dispositivo com o da livre investigação judicial ou iniciativa oficial, na medida em que o juiz não mais se limita a assistir inerte à produção de provas, pois a princípio pode e deve assumir a iniciativa destas, juntamente com as partes.

\subsection{Princípio da imparcialidade do juiz}

A expressão imparcial refere-se ao que julga sem paixão; reto; justo.

\footnotetext{
${ }^{13}$ Nesse sentido, aduz Barbosa Moreira: "ainda que as partes possam dispor de seus direitos, nenhum poder de disposição têm elas sobre o poder do juiz de averiguar o fato." MOREIRA, José Carlos Barbosa, apud PACÍFICO, Luiz Eduardo Boaventura. O ônus da prova no direito processual civil. São Paulo: Revista dos Tribunais, 2000. p. 148.
} 
Na relação jurídica processual, juiz imparcial é aquele que está eqüidistante das partes, ou seja, é aquele que se coloca entre "as partes e acima delas." 14

A imparcialidade visa assegurar a legitimidade do julgador, de modo que a sua decisão seja imune a interferências externas. Não raro, encontramos na doutrina posicionamentos no sentido de que a iniciativa probatória do juiz fere a sua imparcialidade, pois este estaria adotando postura investigativa, com ausência da serenidade necessária à sua missão.

Entretanto, entendemos que juiz imparcial não é sinônimo de juiz inerte, passivo e desinteressado, e tampouco que o juiz, ao determinar a produção de provas, assume o lugar das partes em sua atividade privativa.

Imparcialidade não significa neutralidade diante dos valores a serem resguardados no processo. Não há nenhuma incompatibilidade entre tal princípio e o empenho do juiz, adotando postura ativa, para que realmente vença a parte que tenha seu direito tutelado pelo ordenamento jurídico. Ao contrário, esse é o verdadeiro objetivo do processo. Importa ao juiz conduzi-lo a fim de que seja um real instrumento de justiça, que vença quem realmente tem razão. Nisto consiste a sua imparcialidade.

Entre os argumentos utilizados na doutrina para limitar a atividade instrutória do juiz em razão de ofensa à sua imparcialidade, está a possibilidade de o resultado de uma prova determinada pelo juiz beneficiar uma das partes. Em primeiro lugar, ao determinar a produção de uma prova o juiz não está visando beneficiar qualquer das partes, e sim buscar os elementos necessários à sua convicção. Em segundo lugar, não há como prever qual parte será beneficiada pela produção da prova antes do seu resultado.

Desse modo, nos pareceria parcial o juiz que deixa de determinar a produção de uma prova que possibilitaria o esclarecimento de um fato obscuro, beneficiando, assim, a parte que não tem razão. Há ainda posições que sustentam a participação do Ministério Público, se o litígio versar sobre direitos indisponíveis, com o objetivo de não comprometer a imparcialidade do juiz.

Nesse sentido, tais autores aduzem à norma contida no art.83, inc.II, do CPC, que estabelece que, nas causas em que atue como custus legis (art.82), o parquet "poderá juntar documentos e certidões, produzir prova em audiência e requerer medidas ou diligências necessárias ao descobrimento da verdade."

\footnotetext{
${ }^{14}$ CINTRA, Antônio Carlos de Araújo; GRINOVER, Ada Pellegrini; DINAMARCO, Cândido Rangel, apud BRAGA, Sidney da Silva. Da iniciativa probatória do juiz no processo civil. São Paulo: Saraiva, 2004. p. 117.
} 
No entanto, como bem pondera José Carlos Barbosa Moreira, tal norma não proíbe o juiz de atuar quando haja a iniciativa do parquet, nem tampouco, ao contrário, faz supor que o juiz deva atuar mais (ou só) nas causas em que o Ministério Público também atue. ${ }^{15}$

Enfim, a postura ativa do juiz na determinação de provas não afeta sua imparcialidade, na medida em que adotando tal postura, contribui para que o processo atinja não só seus escopos jurídicos, mas também sociais, políticos e filosóficos. O juiz deve sim ter interesse no resultado do processo, a fim de se alcançar justiça!

Por fim, deve-se registrar que para a manutenção da imparcialidade do juiz na determinação de provas, basta que se permita às partes se manifestarem sobre elas, através do contraditório, como será demonstrado a seguir.

\subsection{Princípio do contraditório}

O contraditório, como corolário da garantia do devido processo legal, encontra-se estampado na Constituição Federal, em seu art. $5^{\circ}$, inc.LV, que dispõe, in verbis: "LV - aos litigantes, em processo judicial ou administrativo, e aos acusados em geral são assegurados o contraditório e ampla defesa, com os meios e recursos a ela inerentes."

Assim, o contraditório é princípio que visa assegurar às partes o direito de participarem do debate processual, através da cientificação dos atos processuais e a possibilidade de opôr-lhes resistência, influenciando no convencimento do juiz. Traduz-se comumente na doutrina pelo binômio "ciência-participação".

O contraditório é sem dúvida, uma garantia da preservação da imparcialidade do juiz, na medida em que este coloca-se acima das partes e eqüidistante delas. Isso significa que cabe ao juiz dar as mesmas oportunidades para que autor e réu se manifestem sobre todos os atos processuais, que exponham suas razões, que apresentem suas provas, influindo no convencimento do magistrado.

Observa-se, sob a ótica do contraditório, a nítida repartição de tarefas entre os sujeitos processuais. De modo particular, dentro dessa divisão de tarefas, a iniciativa probatória não é exclusiva das partes, conforme se infere da leitura do artigo 130 do Código de Processo Civil: “art. 130. Caberá ao juiz, de ofício ou a requerimento da parte, determinar as provas necessárias à instrução do processo, indeferindo as diligências inúteis ou meramente protelatórias." (grifo nosso)

\footnotetext{
${ }^{15}$ MOREIRA, José Carlos Barbosa, apud MATTOS, Sérgio Luís Wetzel de. Da iniciativa probatória do juiz no processo civil. Rio de Janeiro: Forense, 2001. p. 28-29.
} 
Percebe-se claramente que o legislador confere ao juiz a tarefa de produzir provas, juntamente com as partes. O processo, nessa medida, apresenta-se como uma 'obra de colaboração' entre os seus sujeitos, incluindo aí também o juiz; por isso, não se admite mais o isolamento deste.

O contraditório reflete-se diretamente na produção das provas, pois as partes devem ter igualdade de condições para produzi-las e de pronunciar-se sobre os seus resultados, assim como as provas produzidas pelo magistrado também dever se submeter à apreciação dos litigantes. Assim, a garantia do contraditório se revela como instrumento de controle da atividade probatória do juiz, preservando a sua imparcialidade e evitando a arbitrariedade.

Portanto, assegurar às partes o direito à prova não significa atribuir-lhes o monopólio da instrução da causa, haja vista que subsiste intocável a iniciativa probatória do juiz. De outro lado, o poder outorgado ao juiz de assumir provas ex officio não exclui o direito das partes de indicar meios probatórios.

Conclui-se que o juiz, ao determinar provas de ofício, permite a ampla participação das partes, através do contraditório, resguardando, assim, o interesse dos litigantes.

\subsection{Princípio da igualdade processual}

O princípio da igualdade processual ou isonomia é basilar do nosso ordenamento jurídico. Está consagrado na Carta Magna, em seu artigo $5^{\circ}$, caput, e inciso I, in verbis: “Todos são iguais perante a lei, sem distinção de qualquer natureza, garantindo-se aos brasileiros e aos estrangeiros residentes no País a inviolabilidade do direito à vida, à liberdade, à igualdade, à segurança e à propriedade, nos termos seguintes: I - homens e mulheres são iguais em direitos e obrigações, nos termos desta Constituição;”.

O princípio também está consagrado no Código de Processo Civil, art.125, inciso I.: “O juiz dirigirá o processo conforme as disposições deste Código, competindo-lhe: I assegurar às partes igualdade de tratamento".

A igualdade processual, como se pode inferir da leitura do dispositivo processual acima, é direcionada para o Estado-juiz (magistrado, que o representa) no sentido de que deve assegurar igualdade de tratamento às partes, oferecendo-lhes as mesmas oportunidades para alegações e provas. Não poderá também examinar com maior atenção os argumentos e provas de um litigante e fazer uma análise superficial ao que foi levado ao processo pelo outro.

Assim, não há como conceber o processo apenas como palco de duelo entre quem possui melhores condições econômicas e técnicas, em que vença a parte que tem condições de 
contratar um melhor advogado, que saiba as regras e que consiga fazê-las atuar em seu favor, sem, no entanto, ter efetivamente razão diante das normas de direito material.

Justamente para evitar estas situações de desigualdade entre as partes, o legislador vem adotando medidas para reforçar os poderes instrutórios do juiz, pois, embora não caiba ao julgador a solução de tão grave problema social e econômico, cabe a ele empenhar-se para reduzir seus reflexos na esfera processual. Daí a razão do ordenamento jurídico lhe conferir atribuições assistenciais em favor da parte mais fraca. Desse modo, entendemos que o juiz deve determinar a produção de prova sempre que perceber que a parte deixou de produzi-la em razão de deficiência econômica.

Não se pode esquecer que cada sujeito processual desempenha tarefa de colaboração no âmbito do processo. Assim, o juiz não estaria substituindo as partes ou facilitando a atuação de determinado litigante em juízo, mas sim exercendo a parte que lhe cabe dentro de uma tarefa comum, a fim de se chegar à solução justa do litígio.

\subsection{Princípio da persuasão racional do juiz}

Trata-se de princípio que regula os poderes do juiz na apreciação e valoração da prova constante nos autos, indicando que o magistrado deverá formar sua convicção livremente.

Leva em conta a consciência do julgador, libertando-o do critério pré-fixado ou numérico das provas (antigo sistema da prova legal), porém, exige-se que ele fundamente sua decisão com base nas provas carreadas aos autos (quod non est in actis non est in mundo). E mais: tal fundamentação deve ser externada, para que as partes tenham conhecimento de seu conteúdo. Esta exigência, a nosso ver, foi o motivo da consagração do princípio da persuasão racional, pois reduziu a insegurança dos litigantes no processo, ${ }^{16}$ permitindo-lhes maior controle sobre a atividade judicial, o que nos remete ao princípio da motivação das decisões judiciais.

O princípio da motivação ou fundamentação expressa a necessidade de toda e qualquer decisão judicial ser fundamentada, explicada, justificada pelo magistrado que a prolatou. Tal princípio está consagrado no artigo 93, inciso IX, da Constituição Federal.

\footnotetext{
${ }^{16}$ Justifica-se tal insegurança pela adoção do antigo sistema da livre convicção, que vigorava antes da persuasão racional. A livre convicção permitia ao magistrado uma ampla liberdade ao decidir, o que dava certa margem de subjetivismo e arbitrariedade às decisões judiciais.
} 
Assim, o princípio da motivação visa não só conferir transparência aos atos judiciais como também permitir às partes fiscalização sobre eles, evitando, por conseguinte, o arbítrio judicial.

O sistema do livre convencimento do juiz ou persuasão racional é adotado em todos os ordenamentos jurídicos civilizados do mundo. É uma forma de equilibrar autoridade com liberdade. No sistema processual civil brasileiro, o princípio foi adotado no art. 131: "O juiz apreciará livremente a prova, atendendo aos fatos e circunstâncias constantes dos autos, ainda que não alegados pelas partes; mas deverá indicar, na sentença, os motivos que lhe formaram o convencimento."

Assim, a motivação das decisões judiciais é, sem dúvida alguma, uma forma de preservar a imparcialidade do juiz, e a nosso ver, mais um argumento que justifica e autoriza a iniciativa do magistrado para produzir as provas que entender necessárias para o esclarecimento da verdade processual.

\section{O papel do juiz e o ônus da prova}

$\mathrm{Na}$ doutrina brasileira, desenvolve-se interessante debate acerca do reconhecimento dos poderes instrutórios do juiz (art. 130 do CPC) quando colocados tais poderes diante das regras de distribuição do ônus da prova (art. 333 do CPC).

Faz-se necessário uma interpretação conjugada dos mencionados dispositivos, a fim de se buscar uma compatibilização entre as duas normas, para isso transcrevemos os citados artigos: "art.130. Caberá ao juiz, de ofício, ou a requerimento da parte, determinar as provas necessárias à instrução do processo, indeferindo as diligências inúteis ou meramente protelatórias"; o art. 333 reza que "o ônus da prova incumbe: I - ao autor, quanto ao fato constitutivo do seu direito; II - ao réu, quanto à existência de fato impeditivo, modificativo ou extintivo do direito do autor."

Entendemos que as regras do ônus da prova devem ser vistas sob o ponto de vista objetivo, devendo servir para direcionar a conduta do juiz, quando, finda a atividade probatória, e analisando os elementos contidos nos autos, considerar que não foram provados os fatos relevantes para a solução do litígio.

Nessa hipótese, como é proibido ao juiz o non liquet (art. 126 do CPC), ou seja, deixar de decidir sob a argumentação de que não está convencido da verdade, as regras do ônus da prova funcionam como regras de julgamento, que o juiz se vale no momento da sentença. Isso quer dizer que, em tese, o juiz julgará procedente o pedido se o réu, na contestação, não tiver 
provado os fatos impeditivos do direito do autor; ao inverso, julgará improcedente o pedido, se o autor não tiver provado os fatos constitutivos do seu direito alegados na petição inicial, de acordo com as regras do artigo 333 do CPC.

Assim, não há qualquer impedimento ao juiz de utilizar os poderes instrutórios conferidos pelo art.130 em face do artigo 333 do CPC, visto que ele irá desenvolver tal atividade em momento distinto e anterior à sentença.

O fato de o juiz determinar a produção de uma prova de ofício não desnatura a regra de divisão do ônus da prova, pois o magistrado age paralelamente em relação às partes, e não as substituindo em sua atividade probatória.

Assim, a regra estabelecida no art.333 só deve ser aplicada depois que tudo foi feito para se obter a prova dos fatos e tal resultado se mostrou insuficiente. E quando isso ocorre, a prova, uma vez produzida, passa a integrar o processo como um todo, não importando quem a produziu, pois seja de quem for a iniciativa, ela terá o mesmo valor.

\section{Divergências doutrinárias sobre o tema}

\subsection{Doutrina clássica ou tradicional}

A doutrina tradicional, mais conservadora, sempre conferiu papel menos importante ao juiz na produção da prova.

Com efeito, tais autores procuram limitar a iniciativa probatória oficial, afastando as prerrogativas do art. 130 do CPC conferidas ao juiz, procurando ressaltar que ao assumir a investigação dos fatos e buscar a verdade, o julgador estaria ferindo a sua imparcialidade e quebrando a igualdade processual, além de tal atitude configurar desobediência à regra do art.333 do CPC.

Bastante influenciada pela antiga concepção, é clássica, no direito brasileiro, a posição de Moacyr Amaral Santos, interpretando de forma moderada o art.130 do CPC, pois considera que a atividade instrutória do juiz deve ser meramente supletiva ou complementar. ${ }^{17}$

Assim, só quando a prova dos autos gerasse dúvida e perplexidade no espírito do julgador, poderia ele determinar a sua complementação, a fim de melhor esclarecimento da verdade. Pode-se citar como exemplo a conversão do julgamento em diligência, a inquirição de testemunhas referidas, a requisição de documentos a órgãos públicos, etc.

\footnotetext{
${ }^{17}$ SANTOS, Moacyr Amaral. Primeiras Linhas de direito processual civil. 19 ed. São Paulo: Saraiva, 1998. p. 350 .
} 
Arruda Alvim adota posição semelhante, restringindo a aplicação do art.130 às hipóteses em que não opere a teoria do ônus da prova e desde que a atividade instrututória do juiz seja dirigida para sanar incerteza emergente de prova já produzida. O art.130 seria aplicado em momento posterior, diante da insuficiência das provas constantes nos autos e não teria lugar na distribuição do ônus da prova entre os sujeitos processuais. Assim, o juiz nunca deveria subrogar-se no ônus subjetivo da parte inerte ou omissa. ${ }^{18}$

Liebman alerta para o risco de parcialidade do julgador ao determinar as provas de ofício, ressaltando que este deve se manter alheio ao interesse discutido no feito, a fim de ter psicologicamente assegurada a sua imparcialidade. Para ele, há incompatibilidade entre a função de investigação e de decisão, que exerce o magistrado. Em sua visão, o juiz, ao buscar a sentença justa, exatamente por isso, deseja sentir-se livre de qualquer liame em face das possíveis soluções postas à sua apreciação, o que culminaria na quebra da imparcialidade. ${ }^{19}$

Vicente Miranda atenta para o fato de que "o risco de proferir decisões parciais e apaixonadas seria inevitável se o juiz pudesse substituir as partes na pesquisa e demonstração da verdade." 20

Esta doutrina limitadora do poder de iniciativa probatória do juiz encontra respaldo na obra do saudoso mestre José Frederico Marques, cujo entendimento é de que a atividade probatória oficial deve ser complementar, excepcional, nunca substitutiva. Para o citado autor, a iniciativa oficial está vinculada à natureza do direito material controvertido, sendo que nas relações processuais que versam sobre direitos indisponíveis "cessa a preponderância dos interesses das partes, para predominarem os imperativos legais e os interesses de ordem pública", legitimando-se a atividade probatória do juiz, "exercida com mais amplitude que nos casos subordinados ao jus dispositivum dos litigantes." 21

\subsection{Doutrina ampliativa dos poderes instrutórios do juiz}

A doutrina ampliativa sustenta a possibilidade de investigação probatória oficial sem se apegar à necessidade de o autor provar os fatos constitutivos do seu direito e o réu os fatos

\footnotetext{
${ }^{18}$ NETTO, José Manoel de Arruda Alvim apud PACÍFICO, Luiz Eduardo Boaventura. O ônus da prova no direito processual civil. São Paulo: Revista dos Tribunais, 2000. p. 144.

${ }^{19}$ LIEBMAN, Enrico Tullio, apud PACÍFICO, Luiz Eduardo Boaventura. O ônus da prova no direito processual civil. São Paulo: Revista dos Tribunais, 2000. p. 150.

${ }^{20}$ MIRANDA,Vicente. Os poderes do juiz no processo civil brasileiro. São Paulo: Saraiva, 1993.p. 217.

${ }^{21}$ MARQUES, José Frederico. Manual de direito processual civil. 7 ed. São Paulo: Saraiva, 1980. v. 2. p. 248.
} 
que excepcionam os direitos do autor. Nesse sentido, defendem a investigação probatória do julgador concomitante à das partes, e não subsidiária ou dependente desta.

Em regra, delimitam tal atividade apenas pelo respeito ao contraditório, ao objeto do processo delimitado pelas partes (causa petendi) e pelo dever de motivação das decisões judiciais.

A doutrina ampliativa dos poderes instrutórios do juiz entende que, atualmente, o processo civil passa por uma "reformulação do princípio dispositivo". O precursor desta idéia foi Capelletti, que teve papel de destaque ao proceder a verdadeira revisão do princípio em questão. O eminente jurista italiano defendia a denominada "direção material do processo", em substituição à "direção formal do processo". ${ }^{22}$

Nas palavras de Denis Donoso: “de notar-se, contudo, que o processo moderno reclama uma atividade mais presente e intensa do juiz. Uma sociedade que espera justiça não pode se contentar com a mera verdade formal se é possível buscar a verdade real." 23

Concluindo o raciocínio de Capelletti, o processualista defende que o princípio dispositivo está relacionado somente à alegação das partes, não incluindo mais a prova dos fatos alegados, ou seja, deve ser estendida também ao juiz a iniciativa de produzir as provas, pois somente assim o magistrado poderá apurar integralmente os fatos.

Adota posição semelhante Gracimeri Vieira, no sentido de que, o magistrado, como representante do Estado,

\begin{abstract}
deve agir com autoridade, que não se confunde com arbitrariedade. Não pode ser um "juiz fantoche", conduzido pela atuação das partes, como numa representação teatral, chancelando situações contrárias ao direito objetivo (...). Agindo dessa forma, perseguir-se-ia, na fala de Bedaque (2001, p.16), a mentira formal, promovendo a criação de normas que contrariam a ordem jurídica estabelecida. ${ }^{24}$
\end{abstract}

Observa-se a preocupação da autora em evitar que o juiz, adotando postura inerte, se contamine com material fraudulento ou viciado, que eventualmente pode ser levado pelas partes ao processo, defendo, por essa razão, uma postura mais ativa do magistrado.

Denis Donoso também repugna pela inércia do magistrado, se posicionando a favor da sua iniciativa em produção de provas, quando preciso, como já se verifica normalmente nos procedimentos de jurisdição voluntária, a teor do disposto no artigo 1.107 do CPC, que

\footnotetext{
${ }^{22}$ CAPELLETI, Mauro, apud LOPES, João Batista. A prova no direito processual civil. 2 ed. São Paulo: Revista dos Tribunais, 2002.

${ }^{23}$ DONOSO, Denis . O princípio dispositivo e a verdade real no processo civil. Lex.com.br, São Paulo, jun. 2008. Seção Artigos. Disponível em:<http://www.lex.com.br/noticias/artigos/>. Acesso em: 01 jul. 2008.

${ }^{24}$ GAVIORNO, Gracimeri Vieira Soeiro de Castro. O contraditório, as partes e o juiz. Revista de Processo, São Paulo, RT, a. 32, n. 148, p.283-292, jun. 2007. p. 288.
} 
transcrevemos: "art. 1.107. Os interessados podem produzir as provas destinadas a demonstrar as suas alegações; mas ao juiz é licito investigar livremente os fatos e ordenar de ofício a realização de quaisquer provas".

Sérgio Luís Wetzel de Mattos, em monografia sobre o tema, defende a postura do juiz ativo como meio de tornar mais efetivo o processo, ressaltando ainda que a rigor, não existe preclusão quanto à iniciativa do juiz em matéria de prova. ${ }^{25}$

$\mathrm{Na}$ observação arguta dos processualistas Nelson Nery Junior e Rosa Maria de Andrade Nery: "Proposta a ação por iniciativa da parte, o processo se desenvolve por impulso oficial (CPC 262). O poder instrutório do juiz (...) não se configura como exceção ao princípio dispositivo (...)" (grifo nosso).

Não é outra a lição de Dinamarco:

o juiz moderno compreende que só lhe exige imparcialidade no que diz respeito à oferta de iguais oportunidades às partes e recusa estabelecer distinções em razão das próprias pessoas ou reveladoras de preferências personalíssimas. Não lhe tolera, porém, a indiferença. ${ }^{26}$

Nota-se que os autores que defendem a ampliação dos poderes instrutórios do juiz se valem da distinção entre neutralidade e imparcialidade para justificar tal posicionamento, como já havíamos discorrido na parte referente ao princípio da imparcialidade.

Por fim, a defesa do ativismo judicial que nos parece mais contundente é a de José Roberto dos Santos Bedaque, ao afirmar que:

a participação do juiz na formação do conjunto probatório [...] de
forma alguma afeta a sua imparcialidade. [...] A visão publicista deste
(processo), exige um juiz comprometido com a efetivação do direito
material. Isto é, o juiz pode, a qualquer momento e de ofício,
determinar sejam produzidas provas necessárias ao seu
convencimento. Trata-se de atitude não apenas admitida pelo
ordenamento, mas desejada por quem concebe o processo como
instrumento efetivo de acesso à ordem jurídica justa. ${ }^{27}$

Sustenta o autor que o art. 130 do CPC deve ser interpretado de maneira mais ampla possível, destacando a orientação do direito estrangeiro, que adota a mesma tendência. Em suma, afasta por completo todos os empecilhos normalmente apontados pela doutrina tradicional.

\footnotetext{
${ }^{25}$ MATTOS, Sérgio Luís Wetzel de. Da iniciativa probatória do juiz no processo civil. Rio de Janeiro: Forense, 2001. p. 103-104.

${ }^{26}$ DINAMARCO, Cândido Rangel, apud GOMES, Sérgio Alves. Os poderes do juiz na direção e instrução do processo civil. Rio de Janeiro: Forense, 1997. p. 256.

${ }^{27}$ BEDAQUE, José Roberto dos Santos, apud ALMEIDA, Roberto Sampaio Contreiras de. Os poderes instrututórios do juiz no processo civil e a instrumentalidade do processo. Revista de Informação Legislativa, Brasília, Senado, a. 38, n.150, p. 89-100, abr./jun. 2001.p. 98.
} 
Cumpre registrar neste momento a tendência da iniciativa probatória do juiz também na jurisprudência, conforme ementa do acórdão do Colendo Superior Tribunal de Justiça, publicado no Diário da Justiça eletrônico do dia 07/05/2009 :

"Ementa: PROCESSUAL CIVIL. EMBARGOS DO DEVEDOR À EXECUÇÃO FUNDADA EM TÍTULOJUDICIAL. ÔNUS DA PROVA. INICIATIVA PROBATÓRIA DO JULGADOR.ADMISSIBILIDADE.

- Os juízos de $1^{\circ}$ e $2^{\circ}$ graus de jurisdição, sem violação ao princípio da demanda, podem determinar as provas que lhes aprouverem, a fim de firmar seu juízo de livre convicção motivado, diante do que expõe o art. 130 do CPC.

- A iniciativa probatória do juiz, em busca da verdade real, com realização de provas de ofício, é amplíssima, porque é feita no interesse público de efetividade da Justiça.

- Embora recaia sobre o devedor-embargante o ônus de demonstrar a inexatidão dos cálculos apresentados pelo credor-exequente, deve-se admitir a iniciativa probatória do julgador, feita com equilíbrio e razoabilidade, para aferir a exatidão de cálculos que aparentem ser

inconsistentes ou inverossímeis, pois assim se prestigia a efetividade, celeridade e equidade da prestação jurisdicional. Recurso especial improvido." ${ }^{28}$ (grifo nosso)

Verifica-se assim, que há uma tendência no fortalecimento dos poderes instrutórios do juiz. No processo civil da atualidade, deve ser afastada a verdade formal, corolário do princípio dispositivo, e vigorar a verdade real. Ou seja, ao juiz deve-se dar oportunidade para conhecer os fatos que não sejam somente aqueles trazidos pelas partes ao processo, o que poderia levá-lo a uma decisão parcialmente verdadeira, pois estaria diante de uma verdade formal; ao contrário, deve ser lícito ao julgador verificar os fatos em busca da verdade real, chegando o mais perto possível da realidade fática, a fim de proferir uma decisão justa.

Com efeito, não se justifica buscar a verdade real e concreta dos fatos apenas no processo penal, quando se pode e existem meios para fazê-lo no processo civil. Não deve haver distinção nesse sentido, pois o processo, embora trate de matérias diferentes, é um só.

Sabe-se que o juiz, ou melhor, o Poder Judiciário, não é o responsável por dirimir as desigualdades sociais, econômicas, culturais, existentes na sociedade, incumbindo este papel aos poderes Executivo e Legislativo, assim como assegura a Constituição Federal.

Porém, segundo o ensinamento de Dalmo de Abreu Dallari, como órgão que representa o Estado, não há como negar que o juiz exerce função eminentemente política, a

\footnotetext{
${ }^{28}$ STJ, $3^{\text {a }}$ T., REsp no 1012306 / PR. Rel. Min. Nancy Andrighi.
} 
começar pelas normas que aplica, que têm caráter político, vez que são feitas pelo Legislativo. Além disso, o juiz, ao decidir ou ordenar, não atua como indivíduo, mas sim como agente público, o que significa que tem certa parcela de discricionariedade e poder de coação, sendo responsável pela consecução do objetivo social visado pelo Estado, qual seja, o bem comum. $^{29}$

A discricionariedade, nas palavras de Flávia Moreira Guimarães Pessoa, "se caracteriza por uma faculdade do aplicador do direito para escolher, dentre uma pluralidade de meios - também possibilitados pela lei - o alcance do fim que direciona o interesse da Administração." 30

Assim, está claro que as normas gerais e abstratas que compõem o ordenamento jurídico não são aplicadas automaticamente, necessitando serem interpretadas e terem o seu alcance extraído pelo julgador, que as aplica no caso sub judice. Daí a parcela de discricionariedade conferida ao juiz, pois a rigor, as normas positivadas traçam linhas gerais, que necessitam de complementação pelo magistrado, diante da complexidade de controvérsias que julga.

Ressalte-se, conforme o ensinamento de Marcus Firmino Santiago, que a discricionariedade "não é irrestrita, subordinando-se permanentemente aos limites extraídos do plano normativo constitucional." 31

No entanto, existem críticas quanto à discricionariedade judicial, pois essa compreensão do juiz pode em muito se afastar daquilo que a lei efetivamente determina, haja vista que carrega alta dose de pessoalidade.

Há ainda autores, como Tereza Arruda Alvim Wambier, que não admitem a discricionariedade do juiz, “cuja função, quer proferindo interlocutórias, quer sentenciando, é a de dizer o direito, o que não pode ser feito de dois ou mais modos diferentes, sob pena de que se chegue a comprometer o próprio princípio da legalidade." 32

Eros Roberto Grau, do mesmo modo, repudia a existência da discricionariedade judicial, pois acredita que o juiz, ao interpretar normas, realiza atividade vinculada. Para ele, o

\footnotetext{
${ }^{29}$ DALLARI, Dalmo de Abreu. O poder dos juízes. São Paulo: Saraiva, 1996. p. 88

${ }^{30}$ PESSOA, Flávia Moreira Guimarães. O julgamento como opção ética e a discricionariedade judicial. Revista Espaço Acadêmico. n. 65. out. 2006. Disponível em <http://www.espacoacademico.com.br/065/65pessoa.htm $>$. Acesso em 9 jun. 2010.

${ }^{31}$ SANTIAGO, Marcus Firmino. Constitucionalização do Processo Civil. Tex.pro.br. Seção Artigos. Disponível em <http://www.tex.pro.br/wwwroot/01de2005/constitucionalizacao_do_processo_claudio_firmino.htm> Acesso em: 05 jun. 2010.

32 WAMBIER, Tereza Arruda Alvim. Anotações sobre o ônus da prova. Academia Brasileira de Direito Processual Civil. Porto Alegre, 2006. Seção Artigos. Disponível em <http://www.abdpc.org.br/abdpc/artigos/Teresa\%20Arruda\%20Alvim\%20Wambier\%20-\%20formatado.pdf> Acesso em: 09 jun.2010.
} 
que a doutrina tem denominado de discricionariedade judicial é o poder concedido ao intérprete de criar normas jurídicas baseado num juízo de legalidade e não de oportunidade.

O jurista faz uma distinção entre os dois juízos, estabelecendo que o juízo de oportunidade permite ao intérprete escolher entre diferentes institutos jurídicos, valendo-se do seu subjetivismo, enquanto o juízo de legalidade é uma atividade que o intérprete desenvolve utilizando-se da prudência, mas orientado pela lei e pelos fatos. ${ }^{33}$

Nesse contexto, a discricionariedade deve ser entendida como o compromisso do juiz com o processo justo, pautado em decisões éticas e, a nosso ver, a sua atividade probatória é um meio para, senão atingir, ao menos buscar esse fim.

Além disso, deve o juiz estar sempre atento para que a sua atividade probatória seja externada nas virtudes de prudência e razoabilidade, afim de não transformá-la em arbitrariedade, extrapolando os limites da lei. Para tanto, há que observar o princípio do devido processo legal, propiciando às partes ampla participação no debate processual, assegurada a ampla defesa.

\section{Diligências probatórias ordenadas de ofício pelo juiz}

O CPC prevê, em vários dispositivos, a iniciativa oficial no que concerne à produção de provas. Citamos alguns exemplos:

a) Em relação à prova testemunhal, durante a audiência de instrução e julgamento, o juiz pode determinar, de ofício, a inquirição de testemunhas referidas nas declarações da parte ou das testemunhas, quando entender necessária e a parte não tiver requerido (CPC, art.418, I). Igualmente, também lhe é lícito determinar a acareação entre as testemunhas e entre estas e as partes, para solucionar divergência de depoimentos tendente a esclarecer fato relevante para a causa (CPC, art.418, II).

b) Em caso de prova pericial, cabe ao juiz a nomeação do perito, que deve possuir habilitação técnica e idoneidade moral para assumir compromisso como auxiliar do juízo. Ao magistrado cabe indeferir os quesitos impertinentes e formular os que entender necessários ao esclarecimento da causa ( CPC, art.426). Além disso, o juiz, de ofício, pode determinar a realização de nova perícia, quando entender que a matéria objeto da causa ainda

\footnotetext{
${ }^{33}$ PESSOA, Flávia Moreira Guimarães. O julgamento como opção ética e a discricionariedade judicial. Revista Espaço Acadêmico. n. 65. out. 2006. Disponível em <http://www.espacoacademico.com.br/065/65pessoa.htm $>$. Acesso em 9 jun. 2010.
} 
não se encontra suficientemente esclarecida (CPC, art. 437). Na ação de investigação de paternidade, por exemplo, ainda que as partes deixem de requerer prova pericial, poderá o juiz determiná-la de ofício, (inclusive o exame de DNA, que, contudo, não é sempre indispensável).

c) No tocante à prova documental, amplos também são os poderes conferidos ao juiz para a sua determinação. Exemplo disso são: a exibição de documento ou coisa (CPC, art. 355), a exibição parcial de livros e documentos que esteja em poder da parte (CPC, art. 382), a requisição às repartições públicas de certidões necessárias à prova das alegações das partes e dos procedimentos administrativos nas causas em que forem interessados a União, o Estado, o Município, ou as suas respectivas entidades da administração indireta. (CPC, art. 399, I e II).

d) O juiz pode, em qualquer fase do processo, determinar o comparecimento pessoal das partes a fim de interrogá-las sobre os fatos da causa (CPC, art. 342). É o chamado "interrogatório informal".

e) A lei adjetiva também permite ao magistrado inspecionar pessoas e coisas, em qualquer fase do processo, visando esclarecer sobre fato que interessa à decisão da causa (CPC, art. 440).

Tais exemplos ratificam a ativização do juiz não só no campo da prova, como também na direção do processo, em consonância com as novas tendências de publicização do processo civil. Cumpre ressaltar ainda, que, ao proceder à busca de provas, o juiz deve sempre respeitar outros preceitos constitucionais, tal como prevê o art.5 $5^{\circ} \mathrm{X}$, da $\mathrm{CF}$, o qual transcrevemos em parte: "são invioláveis a intimidade, a vida privada, a honra e a imagem das pessoas (...)".

Desse modo, o magistrado tem a missão de equilibrar autoridade com respeito às liberdades individuais e à dignidade da pessoa humana; somente assim ele atingirá os objetivos almejados não somente pelo legislador, mas por toda a sociedade, na ânsia por justiça.

\section{Limites da iniciativa probatória do juiz}

Para que o juiz, contudo, exerça o seu papel de forma adequada, o sistema processual e a Constituição disciplinam meios para se limitar a sua atividade probatória. Assim, o exercício desses poderes não é ilimitado ou absoluto; caso contrário, estaríamos diante da adoção do sistema inquisitivo puro, que não foi, definitivamente, opção do nosso legislador. 
$\mathrm{Na}$ doutrina, encontram-se cinco limites bem claros e definidos quanto à iniciativa probatória oficial:

1. respeito ao objeto do processo;

2. respeito ao contraditório;

3. dever de motivação das decisões judiciais;

4. natureza lícita das provas a serem determinadas de ofício;

5. caráter relativo da verdade processual, de modo que o juiz, ao buscá-la, deve agir em consonância com a celeridade processual e a viabilidade econômica do processo.

O primeiro limite imposto ao ativismo judicial está em que a iniciativa probatória do juiz deve limitar-se aos fatos controvertidos do processo levados pelas partes, não lhe sendo permitido alterar a causa petendi (ou objeto da ação), introduzindo fatos ou fundamentos novos.

Trata-se do princípio da correlação da sentença ao pedido, sendo vedado ao juiz, sob pena de nulidade, proferir sentença extra petita, citra petita ou ultra petita, leia-se, fora, aquém ou além do pedido do autor, respectivamente.

Não configuram, porém, indevida ampliação do objeto do processo, a determinação de provas relacionadas com fatos que implicam em questões de ordem pública, visto que o juiz tem o dever de conhecê-las de ofício, como as condições da ação.

Um segundo limite bastante claro à iniciativa oficial reside no respeito ao princípio do contraditório. Assim, uma vez determinada a produção de prova de ofício pelo juiz, cabe às partes não só a sua participação na colheita direta dessa prova; mas também a indicação e a produção de outras, ainda que de natureza diversa, que possam complementar ou até mesmo contrariar aquelas determinada pelo juiz . É a chamada contraprova.

Além disso, o contraditório, garantindo a participação do autor e réu, nas palavras de Sidney da Silva Braga, "elimina qualquer hipótese de prejuízos porventura decorrentes do desconhecimento, pelo magistrado, de detalhes ou pormenores envolvidos na prova e que somente poderiam vir à tona pela atividade da própria parte atingida." 34

O dever de motivação das decisões judiciais também constitui importante freio contra a parcialidade ou arbitrariedade do juiz, ao proceder à iniciativa probatória. É imprescindível que, ao fundamentar sua decisão, o juiz mencione, ainda que de forma sucinta, a pertinência com o objeto do processo, a relevância da prova, e principalmente, a sua necessidade, para que se alcance a verdade processual e conseqüentemente, a justiça da decisão.

\footnotetext{
${ }^{34}$ BRAGA, Sidney da Silva. Da iniciativa probatória do juiz no processo civil. São Paulo: Saraiva, 2004. p.137.
} 
As partes exercem controle sobre a iniciativa probatória oficial através dos recursos, e a sociedade também o exerce, ante a natureza pública do processo. Elimina-se, desta maneira, o risco de ofensa aos princípios da imparcialidade do juiz e da igualdade das partes, além de haver o controle em relação ao objeto do processo, tal qual delimitado pelos litigantes.

O quarto limite da iniciativa probatória oficial se encontra na vedação das provas ilícitas. O princípio da vedação das provas ilícitas se encontra disposto na Constituição Federal, no art. 5, LVI: "são inadmissíveis, no processo, as provas obtidas por meio ilícitos". O que o princípio visa proteger é na verdade, a intimidade das pessoas, nos termos amplos do art. $5^{\circ}, \mathrm{X}, \mathrm{da} \mathrm{CF}$.

Assim, a prova ilícita ou obtida por meios ilícitos, (esta sendo passível de raras exceções, conforme a necessidade do caso concreto), deve ser entendida como não produzida perante o magistrado, não influindo na formação da sua convicção. Diante disso, seria impossível conceber a hipótese de o próprio magistrado produzi-la, sob pena de violação a preceito constitucional.

Registre-se que há posições divergentes na doutrina em relação ao tema, destacando-se a posição de José Roberto dos Santos Bedaque, para quem "a eventual ilicitude não pode afastar por completo o poder instrutório do juiz" 35

Tal divergência, no entanto, é complexa, e não interessa ao presente trabalho, sendo que, a nosso ver, o juiz não deve determinar a produção de prova vedada pela lei, pois dessa maneira, seria difícil sustentar a busca pela justiça processual possível, em nome de uma prova de resultado presumivelmente duvidoso.

Por fim, tem-se como último limite à iniciativa probatória oficial a verdade processual objetivável, em consonância com os custos e a efetividade do processo. Sabe-se que a verdade absoluta é inatingível no processo, devendo o juiz ter ciência (e consciência) de que sua decisão nunca será tomada em estado de plena certeza acerca dos fatos que compõe o cenário processual. Assim, as decisões judiciais devem contentar-se com determinado grau de probabilidade, maior ou menor, dependendo de cada caso concreto.

Diante dessa realidade, o juiz deve agir com bom senso e cautela ao aprofundar a investigação probatória, pois tal iniciativa pode se tornar dispendiosa para a parte, além de haver a possibilidade de tornar o processo mais moroso, colocando-se como mais um entrave à prestação jurisdicional, já tão criticada por sua lentidão e falta de efetividade.

\footnotetext{
${ }^{35}$ BEDAQUE, José Roberto dos Santos. Poderes instrutórios do juiz. São Paulo: Revista dos Tribunais, 1991.p. 100.
} 
O que se mostra de bom tom é o juiz, antes de determinar a produção de uma prova não requerida pelas partes, auferir e comparar os eventuais benefícios que ela poderá trazer, em busca de uma verdade processual possível naquele caso, com os eventuais prejuízos decorrentes do aumento estimado da duração do processo e do seu custo para as partes.

\section{CONCLUSÃO}

Não há como conceber, diante do estágio atual da ciência processual, com o olhar voltado para os fins não somente jurídicos, mas também políticos, sociais - e, sobretudo éticos do processo, que a sorte dos litigantes fique condicionada a uma decisão precária, descabida, resultante de uma postura inerte e descompromissada do juiz com os verdadeiros fins do processo.

A justiça é um direito essencial do cidadão e por isso, não pode ser disponível. Assim, a jurisdição deve ser entendida como um modo para que o Estado atinja suas finalidades.

Hoje, não só a legislação pátria, mas também a maioria das legislações estrangeiras, nitidamente influenciadas pelas idéias de instrumentalidade do processo, conferem papel amplo e ativo ao julgador na condução e instrução do processo. Portanto, para que se legitime a iniciativa do juiz em matéria de prova, é necessário que os operadores do direito adquiram uma visão publicista do processo.

Constatou-se que o tema da atividade instrutória do juiz desperta divergências e posicionamentos variados na doutrina, podendo-se verificar desde posicionamentos mais liberais, que conferem ampla iniciativa probatória ao magistrado, passando pelos posicionamentos moderados, que legitimam a iniciativa instrutória oficial, desde que seja necessária para esclarecimento dos fatos, resguardados o contraditório, a igualdade processual e a imparcialidade; até os posicionamentos que conferem ínfimas hipóteses ou simplesmente negam a possibilidade de o juiz produzir provas, tendo por fundamento o princípio dispositivo e a natureza disponível do direito material.

O nosso entendimento se coaduna ao posicionamento moderado, pois pensamos que o juiz deve agir sempre que entender necessário para esclarecer fato relevante à decisão da causa, sem o qual não poderia proferir decisão com a consciência tranqüila. Isso é o que prevê a nossa legislação, como dispõe o artigo 130 do CPC, ao possibilitar que o juiz determine, de ofício, as provas necessárias à instrução da causa. 
Conforme salientamos, o juiz deve agir sempre em busca da verdade. Ainda que não venha a obter a verdade absoluta e límpida dos fatos, o magistrado não pode se escusar de conhecer a realidade dos fatos sob seu julgamento, o tanto quanto possível, para que tenha condições de cumprir a função que lhe foi outorgada pelo Estado, qual seja, a pacificação social através da jurisdição.

Assim é que tradicionais dogmas da ciência processual, tais como os princípios dispositivo, da imparcialidade, do contraditório, da igualdade processual e as regras do ônus da prova, vêm sendo reformulados, pois, conforme demonstramos, não há incompatibilidade entre eles e a iniciativa probatória do juiz.

Fica claro que o juiz deve ser imparcial, no sentido de dar razão a quem efetivamente a tem, mas para isso não deve se manter neutro, desinteressado e conformado com as deficiências instrutórias deixadas pelas partes.

A postura protocolar e burocrática do juiz deve ser repugnada pelo ordenamento jurídico e por toda a sociedade.

Diante de todas essas prerrogativas, o próprio sistema processual e a Constituição dispõem de meios para controlar e limitar a atividade do juiz. Dessa maneira, não há como falar em adoção pura do princípio inquisitivo, o que implicaria em retrocesso diante das garantias asseguradas aos cidadãos com a Constituição de 1988.

É importante frisar que o juiz não deve agir em substituição à atividade das partes, mas sim exercer a parte que lhe cabe dentro da tarefa de colaboração comum que deve existir entre os sujeitos processuais.

Todas essas considerações decorrem do entendimento de que acima do interesse privado das partes, deve estar o interesse público do processo. Por tudo, conclui-se que a prova deve pertencer a todos os sujeitos processuais: às partes, porque procuram demonstrar os fatos favoráveis aos seus interesses e ao juiz, por que é o meio de se alcançar os escopos do processo.

Finalmente, ficam a reflexão e a indagação se basta apenas a lei conferir papel participativo ao juiz, sem, no entanto, o Judiciário disponibilizar meios materiais e humanos para que o juiz tenha condições de efetivar o papel que é chamado a desempenhar dentro de uma sociedade tão desigual como a brasileira. Há que se considerar também a falibilidade e as paixões humanas, que muitas vezes impedem o juiz de desempenhar seu papel com a objetividade e serenidade necessárias.

É preciso que os juízes, antes de tudo, tenham consciência de sua missão e do relevante papel jurídico, político e social que exercem, o que equivale também a eliminar o 
excesso de formalismos, que muitas vezes impede a concretização da justiça. Somente assim o juiz será capaz de dar ao seu instrumento de trabalho a dimensão que os tempos exigem.

\section{REFERÊNCIAS}

ALMEIDA, Roberto Sampaio Contreiras de. Os poderes instrututórios do juiz no processo civil e a instrumentalidade do processo. Revista de Informação Legislativa, Brasília, Senado, a. 38, n.150, p. 89-100, abr./jun. 2001.

BEDAQUE, José Roberto dos Santos. Poderes instrutórios do juiz. São Paulo: Revista dos Tribunais, 1991.

BRAGA, Sidney da Silva. Da iniciativa probatória do juiz no processo civil. São Paulo: Saraiva, 2004.

BRASIL. Constituição 1988. Constituição da República Federativa do Brasil. Brasília, DF: Senado, 1988.

Superior Tribunal de Justiça. Recurso Especial n. 1012306 / PR. Relator: Ministra Nancy Andrighi.

Disponível em <http://www.stj.gov.br> Acesso em: 9 jun . 2010.

CAMBI, Eduardo. Direito constitucional à prova no processo civil. São Paulo: Revista dos Tribunais, 2001.v. 3.

CINTRA, Antônio Carlos de Araújo; GRINOVER, Ada Pelegrini; DINAMARCO, Cândido Rangel. Teoria Geral do Processo. 22 ed. São Paulo: Malheiros, 2006.

DALLARI, Dalmo de Abreu. O poder dos juízes. São Paulo: Saraiva, 1996.

DINAMARCO, Cândido Rangel. A instrumentalidade do processo. 11 ed. São Paulo: Malheiros, 2003.

DONOSO, Denis . O princípio dispositivo e a verdade real no processo civil. Lex.com.br, São Paulo, jun. 2008. Seção Artigos. Disponível em:<http://www.lex.com.br/noticias/artigos/>. Acesso em: 01 jul. 2008.

ENTREVISTA com o presidente da $1^{\text {a }}$ Seção do Superior Tribunal de Justiça, ministro Luiz Fux, ao Jornal do Brasil, publicada no site Terra. Disponível em: <http:// noticias.terra.com.br/brasil/interna/0,,0I2892844-EI306,00. html> . Acesso em: 17 mai. 2008.

GAVIORNO, Gracimeri Vieira Soeiro de Castro. O contraditório, as partes e o juiz. Revista de Processo, São Paulo, RT, a. 32, n. 148, p.283-292, jun. 2007.

LOPES, João Batista. A prova no direito processual civil. 2 ed. São Paulo: Revista dos Tribunais, 2002. 
MARINONI, Luiz Guilherme; ARENHART, Sérgio Cruz. Manual do processo de conhecimento: a tutela jurisdicional através do processo de conhecimento. São Paulo: Revista dos Tribunais, 2001.

MARQUES, José Frederico. Manual de direito processual civil. 7 ed. São Paulo: Saraiva, 1980. v. 2.

MATTOS, Sérgio Luís Wetzel de. Da iniciativa probatória do juiz no processo civil. Rio de Janeiro: Forense, 2001.

MIRANDA,Vicente. Os poderes do juiz no processo civil brasileiro. São Paulo: Saraiva, 1993.

PACÍFICO, Luiz Eduardo Boaventura. O ônus da prova no direito processual civil. São Paulo: Revista dos Tribunais, 2000.

PESSOA, Flávia Moreira Guimarães. O julgamento como opção ética e a discricionariedade judicial. Revista Espaço Acadêmico. n. 65. out. 2006. Disponível em <http://www.espacoacademico.com.br/065/65pessoa.htm $>$. Acesso em 9 jun. 2010.

SANTIAGO, Marcus Firmino. Constitucionalização do Processo Civil. Tex.pro.br. Seção Artigos. Disponível em

$<$ http://www.tex.pro.br/wwwroot/01de2005/constitucionalizacao_do_processo_claudio_firmi $\underline{\text { no.htm }>}$

Acesso em: 05 jun. 2010.

SANTOS, Moacyr Amaral. Primeiras linhas de direito processual civil. 19 ed. São Paulo: Saraiva, 1998.

WAMBIER, Tereza Arruda Alvim. Anotações sobre o ônus da prova. Academia Brasileira de Direito Processual Civil. Porto Alegre, 2006. Seção Artigos. Disponível em $<$ http://www.abdpc.org.br/abdpc/artigos/Teresa\%20Arruda\%20Alvim\%20Wambier\%20$\% 20$ formatado.pdf>

Acesso em: 09 jun.2010. 